try) must address the issues in these terms in order to bring about any real change. The results of such efforts should mean that the burden of proof is placed, not on those making a case for retaining the tropical rain-forest, but, more appropriately, on those wishing to remove the forest. They should be obliged to demonstrate that the changes which they propose are genuinely of long-term benefit to the community. This is not an antidevelopment stance, but is rather one of prudent conservation of natural resources as an integral part of a total plan of wise development.

International Earthcare Center

Sierra Club Office of International Environment Affairs 800 Second Avenue

New York

NY 10017, USA.

\section{The Bali Declaration}

Meeting in Denpasar, Bali, from 11 to 22 October 1982, in response to the generous invitation of the Government of Indonesia, the World National Parks Congress considered principles and policies to guide the establishment and management of national parks and other types of protected areas in the light of the broad principles governing the interrelationships among population, resources, environment, and development, formulated by the series of intergovernmental conferences that began at Stockholm in 1972. In drafting the Declaration of the World National Parks Congress, note was taken of the World Conservation Strategy (Anon., 1980) and the Charter for Nature (Anon., 1983). The Congress reaffirmed the fundamental role of national parks and other protected areas in contributing to sustainable development and the spiritual and cultural needs of Mankind. Participants included scientists, planners, managers, and supporters of protected areas, from 70 countries.

DECLARATION OF THE WORLD NATIONAL

PARKS CONGRESS HELD IN BALI, INDONESIA, 11-22 OCTOBER 1982

WE, the participants in the World National Parks Congress, BELIEVE that:

People are a part of Nature. Their spiritual and material well-being depends upon the wisdom applied to the protection and use of living resources. Development needed for the betterment of the human condition requires conservation of living resources for it to be sustainable.

Earth is the only place in the universe known to sustain life, yet as species are lost and ecosystems degraded, its capacity to do so is rapidly reduced, because of rising populations, excessive consumption and misuse of natural resources, pollution, careless development, and failure to establish an appropriate economic order among peoples and among States. The benefits of Nature and living resources that will be enjoyed by future generations will be determined by the decisions of today. Ours may be the last generation to choose large natural areas to protect.

Experience has shown that protected areas are an indispensable element of living resource conservation because:

- they maintain those essential ecological processes that depend on natural ecosystems;
- they preserve the diversity of species and the genetic material within them, thereby preventing irreversible damage to our natural heritage;

- they maintain the productive capacities of ecosystems and safeguard habitats critical for the sustainable use of species; and

- they provide opportunities for scientific research and for education and training.

By doing so, and by providing places for recreation and tourism, protected areas make an essential contribution to sustainable development.

At the same time protected areas serve the spiritual and cultural needs of people by securing the wilderness and sacred areas on which so many draw for aesthetic, emotional, and religious, nourishment. They provide a vital link between us, our past, and our future, confirming the oneness of humanity and Nature.

To these ends, therefore, WE DECLARE the following actions to be fundamental:

1. Expand and strengthen the global and regional networks of national parks and other protected areas, to give lasting security to: representative and unique ecosystems; as full a range as possible of Earth's biotic diversity including wild genetic resources; natural areas that are important for scientific research; and natural areas of spiritual and cultural value.

2. Support the establishment and management of protected areas through national commitment and international development assistance.

3. Provide permanent status for protected areas in legislation securing their objectives against compromise.

4. Plan and manage protected areas, using the best available scientific information; increase scientific knowledge through research and monitoring programmes; and make it readily available to scientists, managers, and the general public throughout the world.

5. Recognize the economic, cultural, and political, contexts of protected areas; increase local support for protected areas through such measures as education, revenue sharing, participation in decisions, complementary development schemes adjacent to the protected area, and, where compatible with the protected area's objectives, access to resources.

6. Implement fully the existing international conventions concerning protected areas, and adopt such new conventions as may be required.

WE PLEDGE ourselves to these actions as a contribution to sustainable development and hence to the spiritual and material welfare of all people; and

CALL UPON all governments, singly and collectively, to take these actions with due dispatch, bearing in mind their responsibility for the whole of life and their accountability to present and future generations.

\section{REFERENCES}

ANON. (1980). World Conservation Strategy: Living Resource Conservation for Sustainable Development. IUCN - UNEP - WWF (obtainable from IUCN, Avenue du Mont-Blanc, 1196 Gland, Switzerland: pack of ca 50 unnumbered pp., illustr., in stiff paper folder).

Anon. (198[3]). World Charter for Nature. United Nations General Assembly, A/37/L.4, 28 October 1982, Thirtyseventh session, Agenda item 21, New York, NY, USA: 7 pp. (mimeogr.). With minor editing the Charter is printed above on pp. 67-8. 